بررسى اثر رزيمهاى مختلف آب آبيارى بر توسعه ريشه و بهرهورى مصرف آب گياه فلفل سبز

فراست سجادى، حسين شريفان و صابر جمالى'”

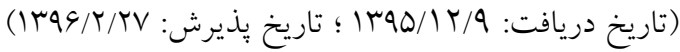

جكيده

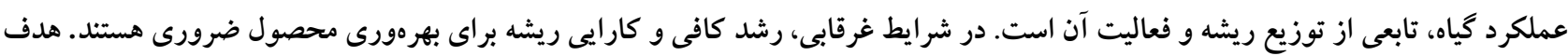

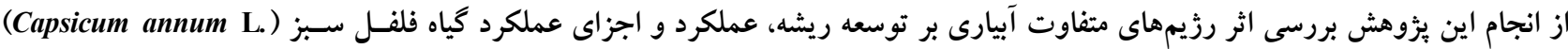

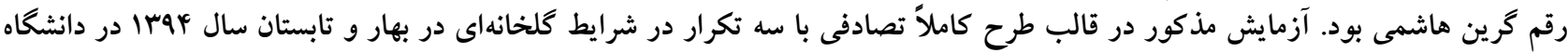

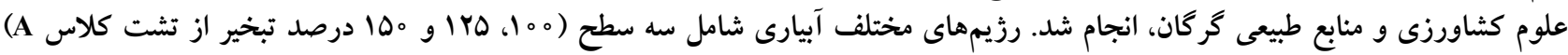

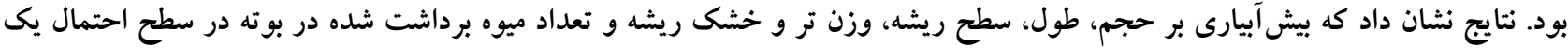

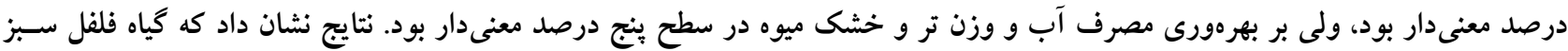

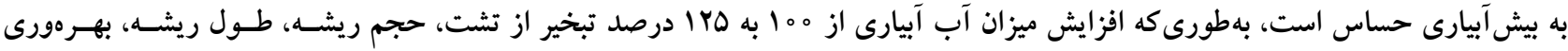

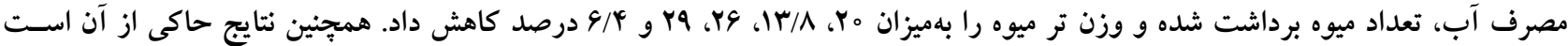
كه افزايش آب آبيارى منجر به كاهش معنىدار وزن تر ميوه شد.

وازمهاى كليدى: بهرهورى مصرف آب، بيشآبيارى، تعداد ميوه، حجم و سطح ريشه، وزن تر ميوه فلفل

ا. كُره مهندسى آب، دانشكده مهندسى آب و خاك، دانشكاه علوم كشاورزى و منابع طبيعى كُركان، كُركان

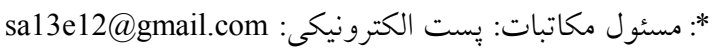


خاك عمق ريشه دوانى را كتترل مى كند. به عقيده ايسن محققـان

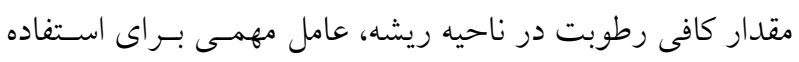

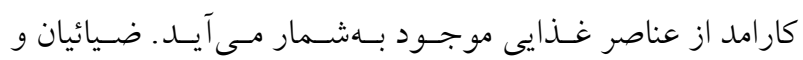

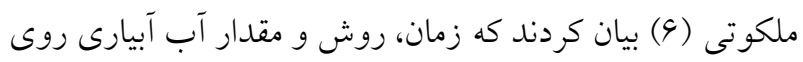
جخونكى توزيع ريشه مؤثر است. در تحقيقى ديخر بهمنظور بررسى اثر مقادير آب آبيـارى بـر

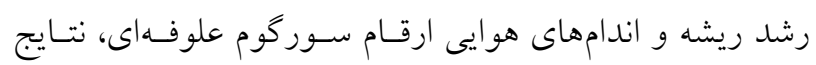

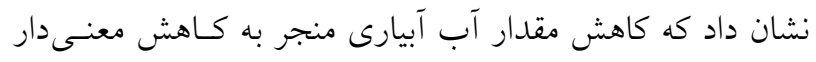

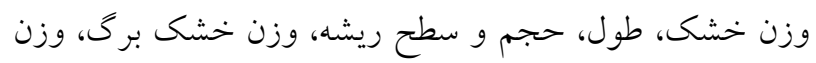

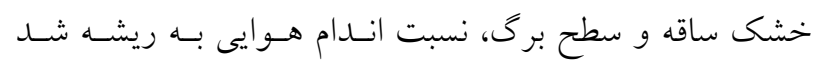

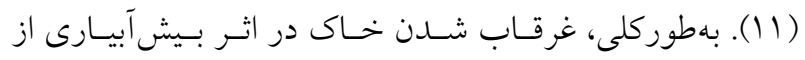

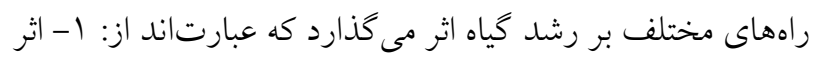

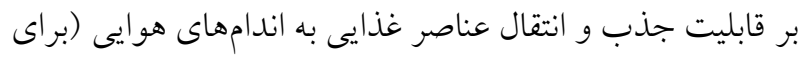

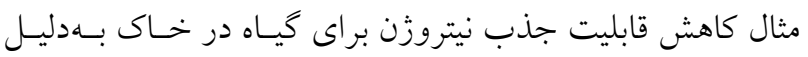

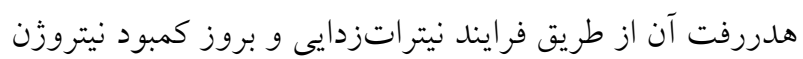

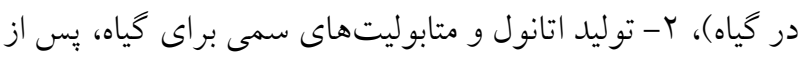
غرقاب شدن خاك، بر اثر كمبـود اكسيزن، در ريشـهـهـاى كيـاه

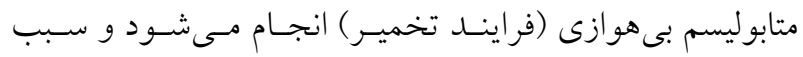
تشكيل و انباشته شدن اتانول و لاكتات مى شود كه به رشـــ كيـاه

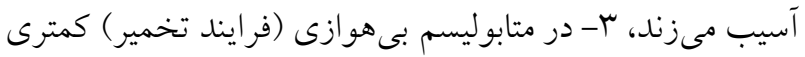
توليد مىشود كه سبب مختـل شـدن وظـايف سـلولهـاى كيـاه

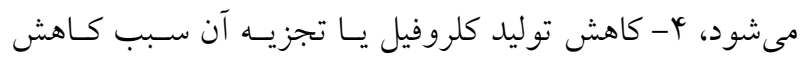

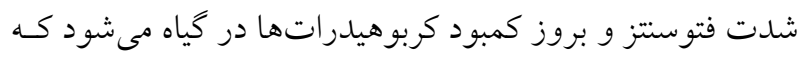

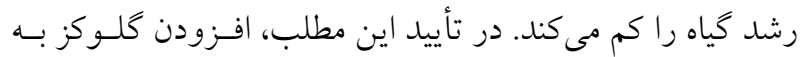

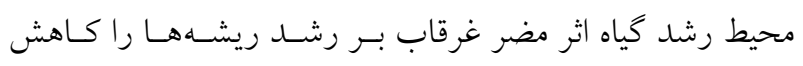

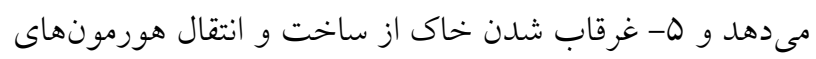

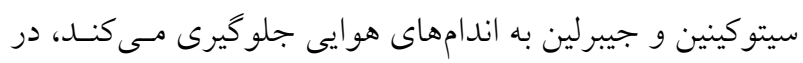

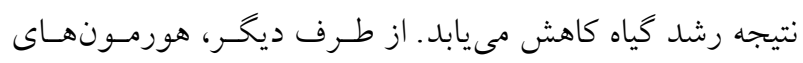

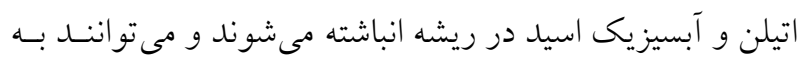

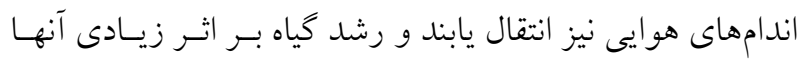

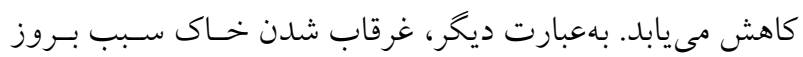

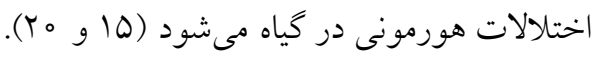

فلفـل قلمسى بــا نـام علمسى (Capsicum annum L.) يكسى از محصولات مهم جاليزى بهشمار مسىرود. اطلاعـات موجـود در

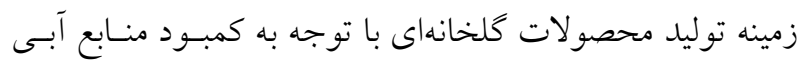
قابل دسترس در بخش كشـاورزى كشـور ايـران محسـدود اسـت.

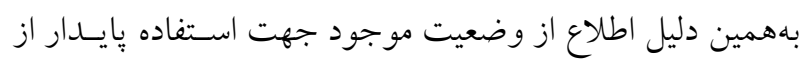

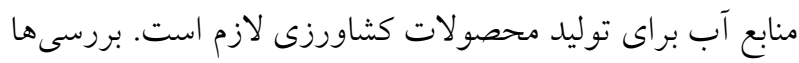

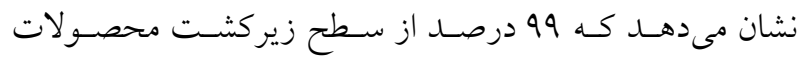

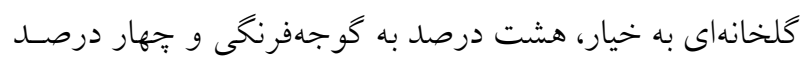

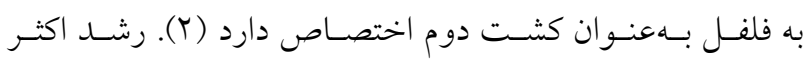

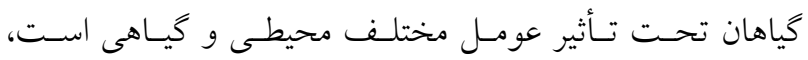

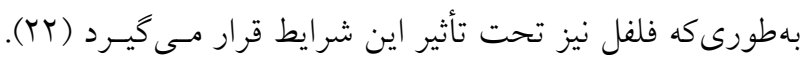

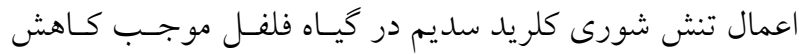
معنىدار رشد ريشه در تيمارهاى شورى نسبت به تيمـار شـاهد شده است (I I). هر يك از شـاخصهـاى رشــ گيـاه از جملـه.

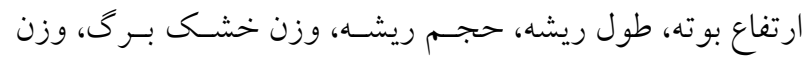
خشى ساقه و وزن خشك ريشه در تنش آبيارى تحت تأثير قرار

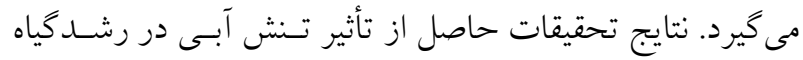

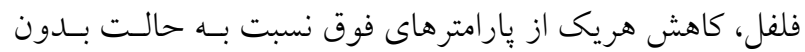
تنش آبى را نشان داده اسـت (سَ). سـالاريان (r) نشـان داد كـه.

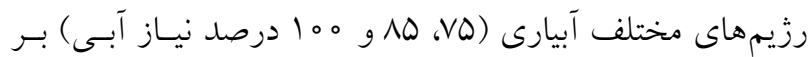

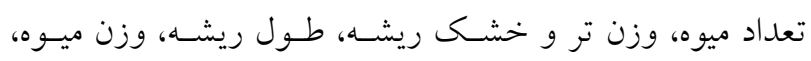

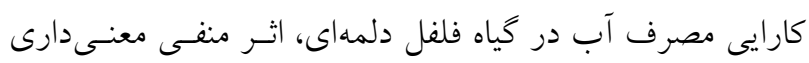

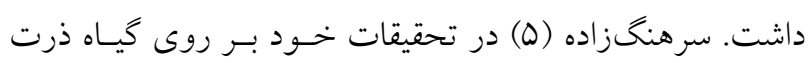

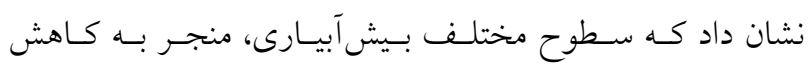
معنى دار وزن تر و خشك ريشه، ارتفاع گياه و قطر ساقه شد.

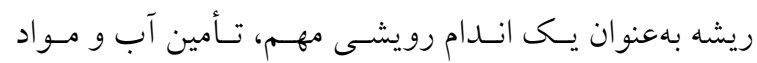

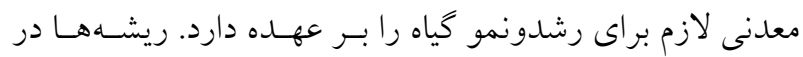
شر ايط عادى قابل مشاهده نبود و اين امر سبب شده اسـت تـا بـا لـا وجود نقش حياتى ريشه در بسيارى از موارد، مسورد توجـه قـرار

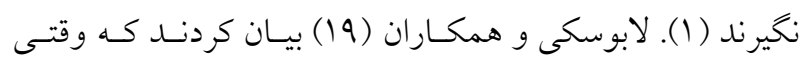

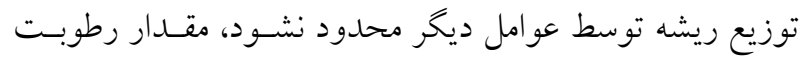




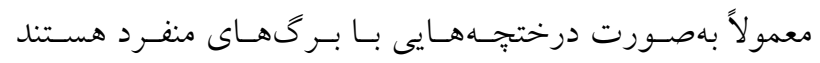

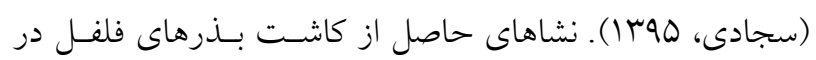

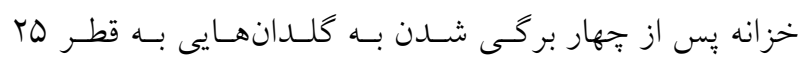

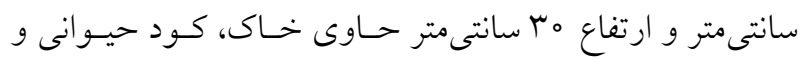

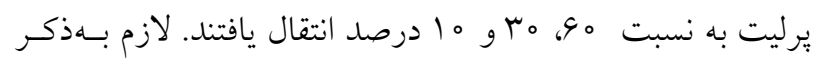

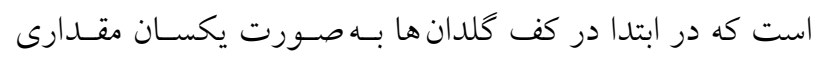

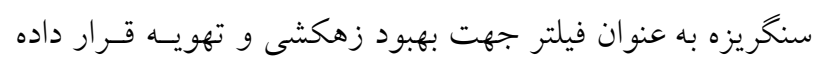

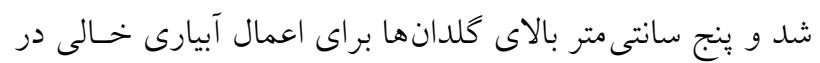

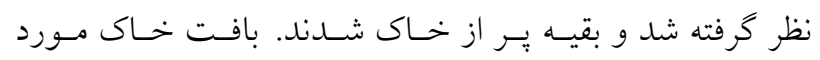

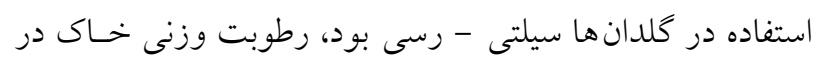

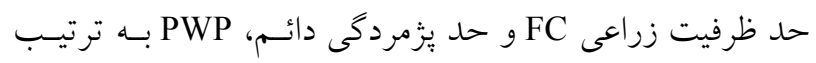
برابر وب درصد و IV درصد وزنى و هدايت الكتريكسى عصـاره

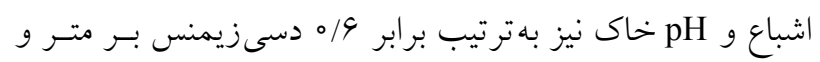

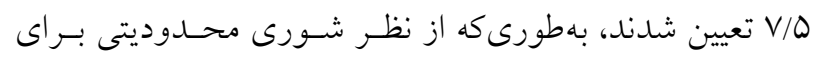

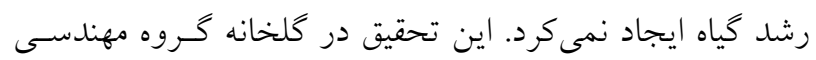

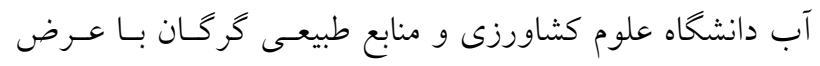

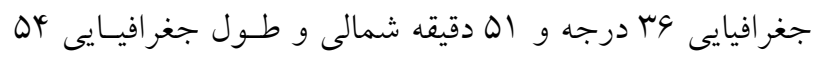

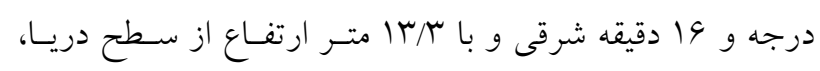

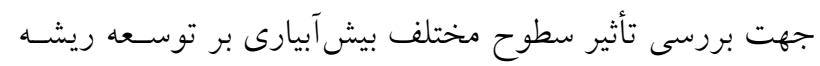

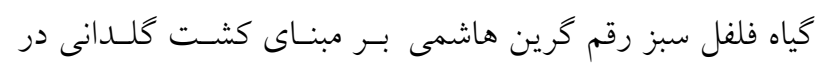

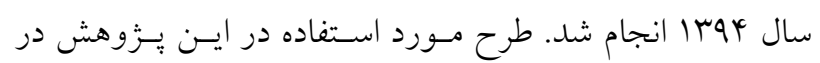

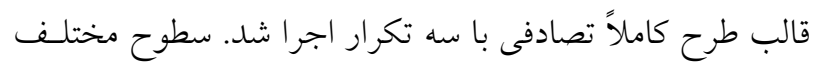

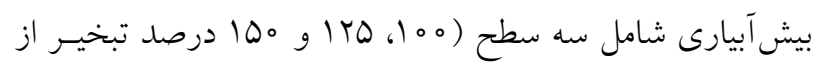

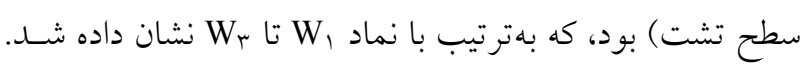

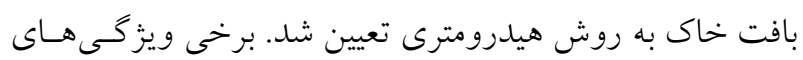

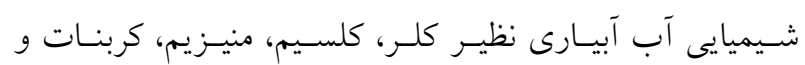

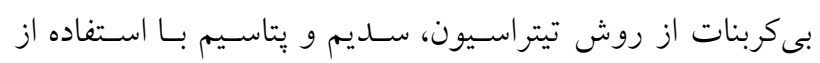

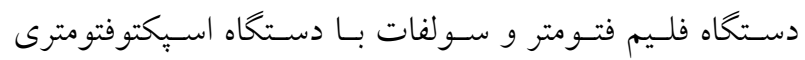

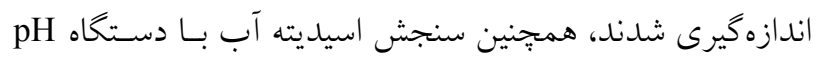

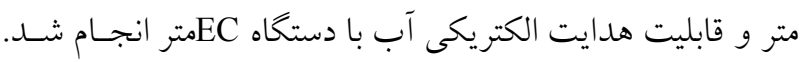

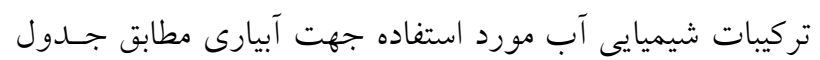
(1) نشان داده شده است.
توسعه ريشههاى كياه علاوهبـر اينكـه يـى صـفت زنتيكسى

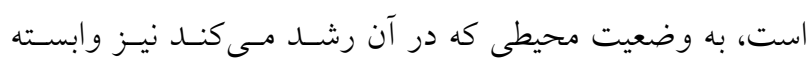

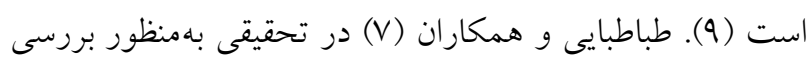
تأثير سطوح مختلف آبى بر رشد، عملكرد و كارايى مصرف آب آب داري

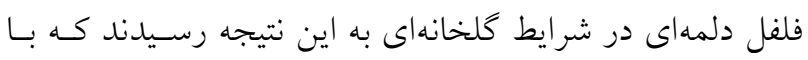

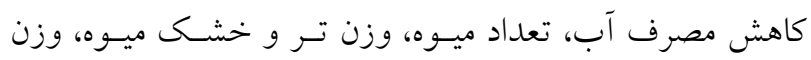

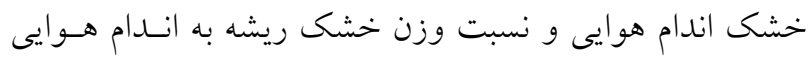
باطور معنى دارى كاهش يافت.

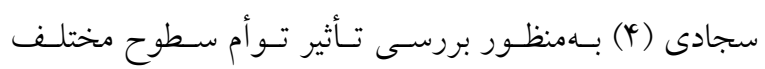

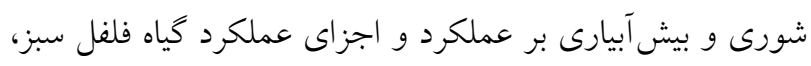

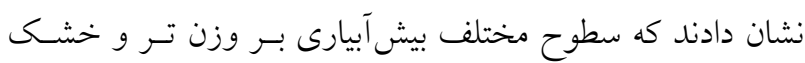

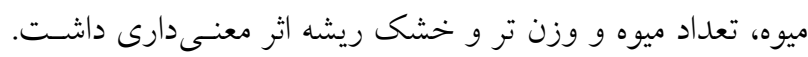

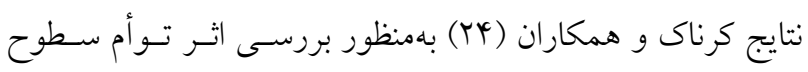
مختلف آبيارى و ارقام مختلف بر عملكرد و اجزاى عملكرد كيـاه

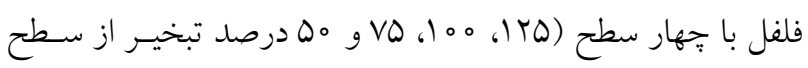

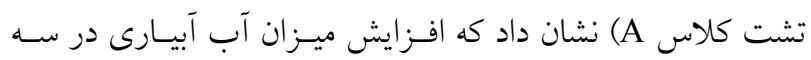

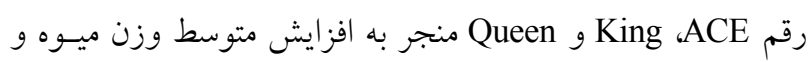
كاهش راندمان مصرف آب شده اسـت. در تحقيقى ديخــ نتـايج

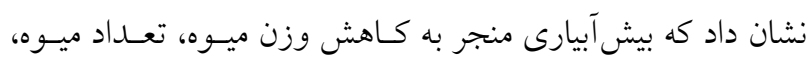

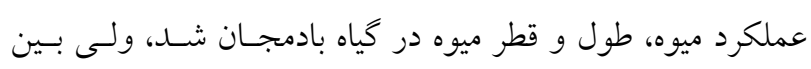

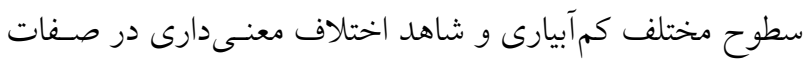

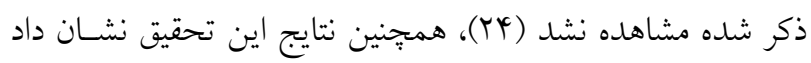
كه بيش آبيارى منجر به كاهش بهرهورى در مصرف مهره آب شد. نتايج

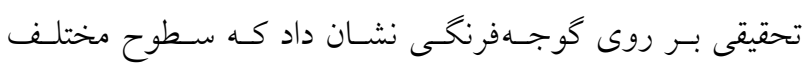

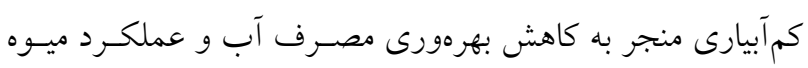

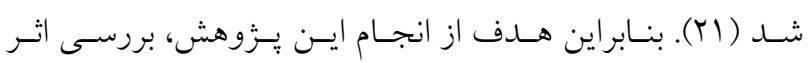

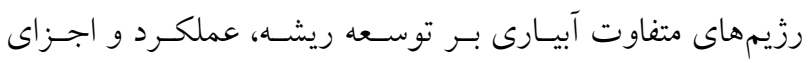
عملكرد گياه فلفل سبز رقم گرين هاشمى بود.

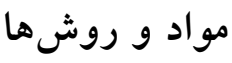
كَاه مورد بررسى در اين يزوهش فلفــل سـبز بـود كـهـ بـهـ تيــره سيبزمينى يا بادمجان (Solanaceae) تعلق دارد. كَاهان اين تيره 
جدول ا. تركيبات شيميايى تيمارهاى آب مورد استفاده در آبيارى

\begin{tabular}{|c|c|c|c|c|c|c|c|c|c|c|c|}
\hline \multicolumn{11}{|c|}{ تركيبات شيميايى } & تيمار آب \\
\hline SAR & $\mathrm{Cl}^{-}$ & $\mathrm{Na}^{+}$ & $\mathrm{K}^{+}$ & $\mathrm{Ca}^{\mathrm{r+}}$ & $\mathrm{Mg}^{\Upsilon+}$ & $\mathrm{SO}_{\psi}{ }^{r-}$ & $\mathrm{CO}_{r}^{-r}$ & $\mathrm{HCO}_{r}^{-}$ & $\mathrm{EC}_{\text {r४ }}$ & $\mathrm{nH}$ & \multirow{3}{*}{ آب شهرى } \\
\hline SAK & \multicolumn{8}{|c|}{$(\mathrm{meq} / \mathrm{L})$} & $(\mathrm{dS} / \mathrm{m})$ & & \\
\hline $0 / 19$ & 1 & $0 / \pi$ & $0 / 1$ & $\varphi / 4$ & $r / \Lambda$ & $0 / V$ & I/OT & $\Delta / \circ \wedge$ & $\circ / 0$ & V & \\
\hline
\end{tabular}

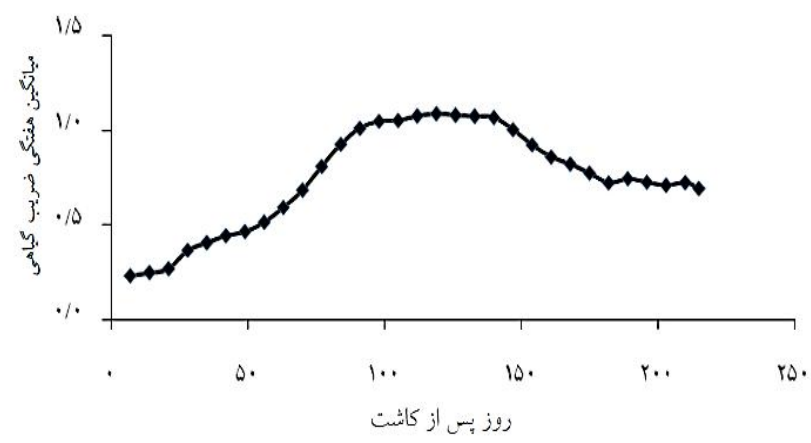

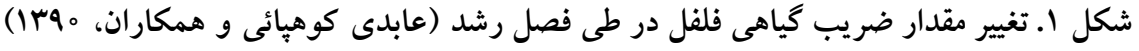

در اين رابطه ETa: ميلى متر بر روز (تبخير تعرق روزانهة)، Kp:

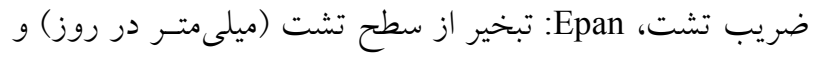

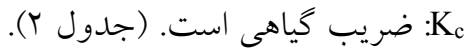

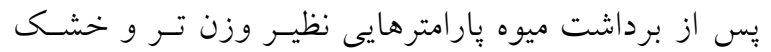
ميوه، تعداد ميوه برداشت شده در بوته و بهرهورى مصرف آب لت تحت رزيمهاى متفاوت آبيارى بررسى شد. جهت اندازه گيرى

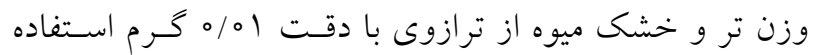
شد، لازم بهذكر است جهت اندازهيرى وزن خشـك ميـوهــا درون پاكت هاى مربوط به هريك از تيمارها قــرار داده شــد و

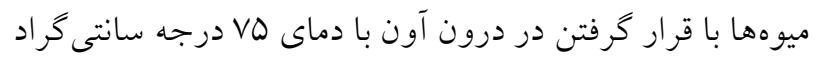

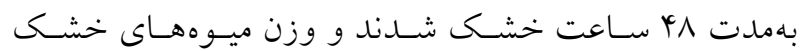

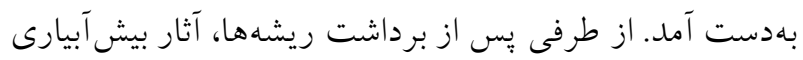

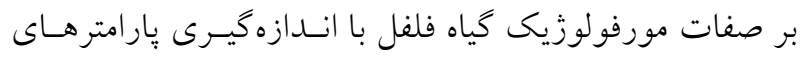

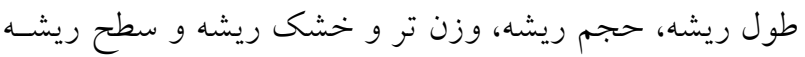
مورد بررسى قرار كرفت. براى اين منظور قسمت هو ايى بوتهـ ونها

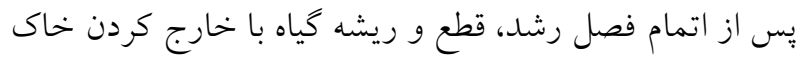

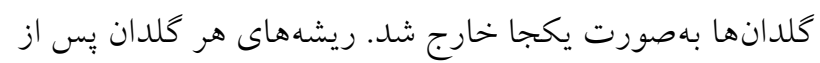

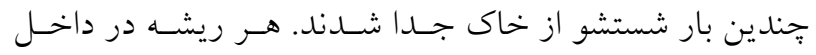
استو انه مدرج با ميزان مشخص آب، كذاشته شد و از روى بـ بـالا
كُلدانها پِ از نشاكارى، به مقدار مساوى آبيارى شدند تا نشاها در محل جديد مستقر شوند. در هر كلدان تراكم بوتهها سه عدد بود. از طرفى يّ از ه إ روز كه فلفلها بـه كلــدان انتقـال داده شد و در كلدانها بهطور كامل استقرار بيدا كرد، بر سـطح بـرى

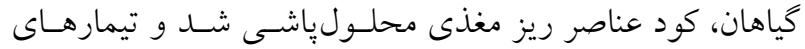

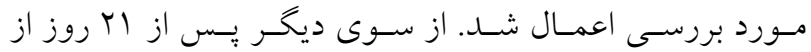

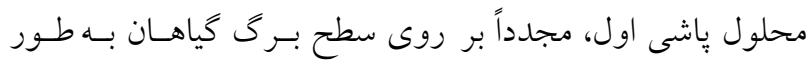
يكسان عناصر ريز مغذى محلولياشى شد. جهت تعيـين مقـدار

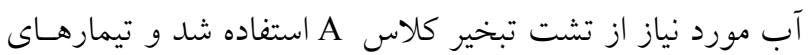

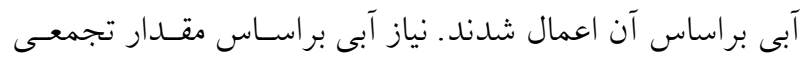

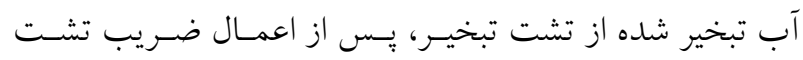

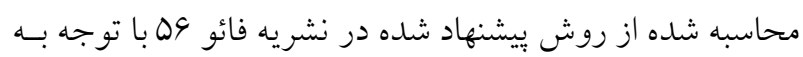

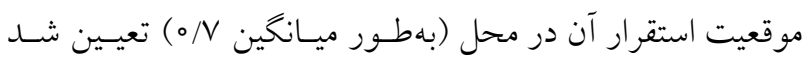

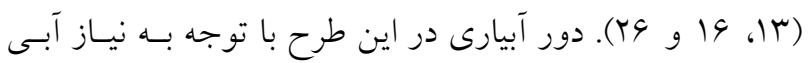

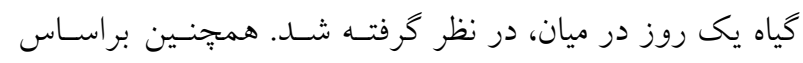

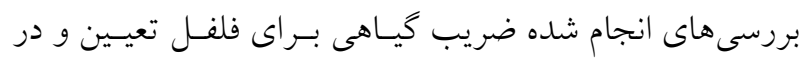

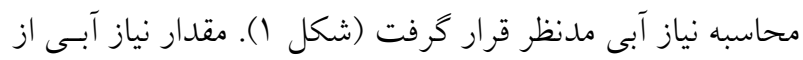

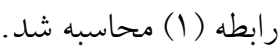
$\mathrm{ET}_{\mathrm{a}}=\mathrm{K}_{\mathrm{c}} \times \mathrm{K}_{\mathrm{p}} \times\left(\mathrm{E}_{\mathrm{pan}}\right)$ 
جدول r. مقادير مختلف ضريب گياهى و طول دوره رشد فلفل

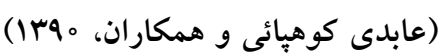

\begin{tabular}{|c|c|c|}
\hline \multicolumn{2}{|c|}{ فلفل } & \multirow{2}{*}{ مرحله رشد } \\
\hline $\mathrm{K}_{\mathrm{c}}$ & طول دوره & \\
\hline$\circ / T \Delta$ & $r_{0}$ & ابتدايى \\
\hline •/dr & ro & توسعه كَاه \\
\hline $1 / \circ r$ & 100 & ميانى \\
\hline -/VQ & 40 & بايانى \\
\hline
\end{tabular}

بيش آبيارى بر صفات اندازهيرى شده حجم، طول، سـطح، وزن

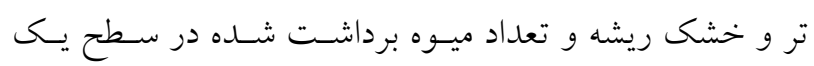

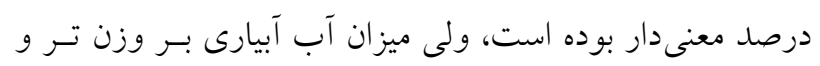

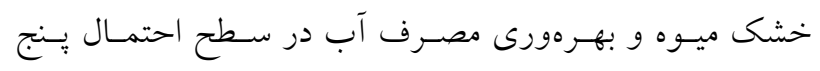
درصد معنى دار بود.

اثر رزيمهاى مختلف آبيارى بر وزن تر و خشك، طول، حجم و سطح ريشه

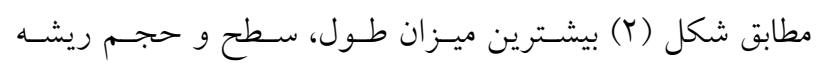

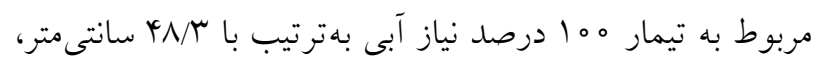

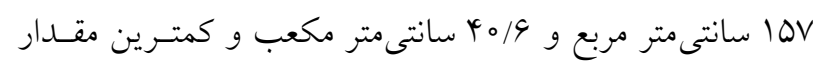

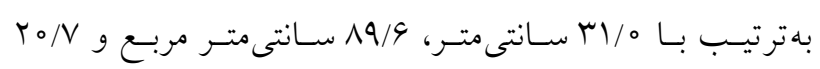

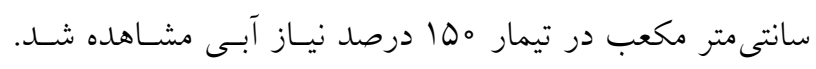

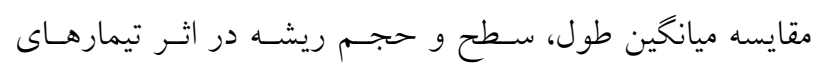

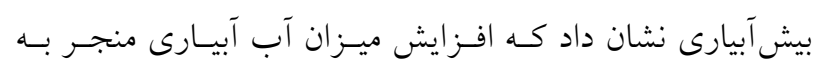
كاهش صفات مذكور شد.

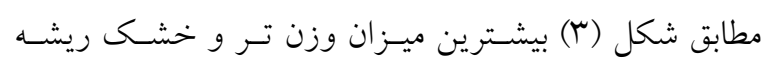

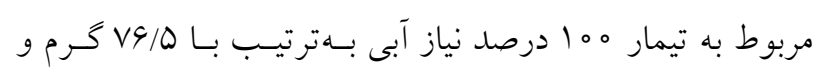

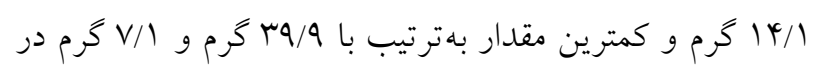

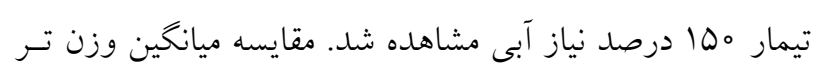

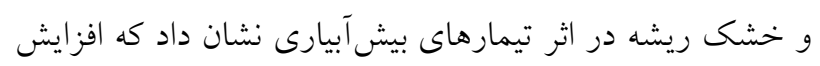
ميزان آب آبيارى منجر به كاهش صفات مذكور شد.

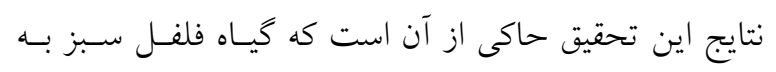

آمدن آب، حجم ريشه برحسب سانتى متر مكعب بهدست آمــ.

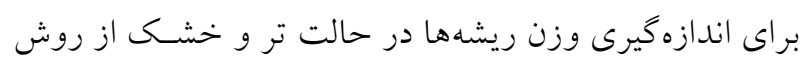

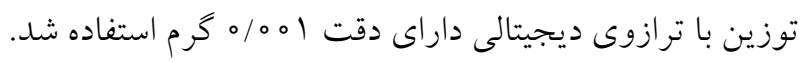

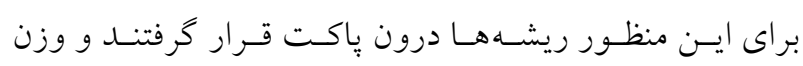

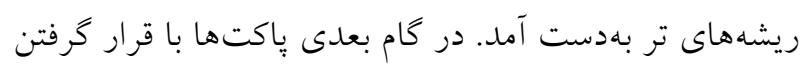

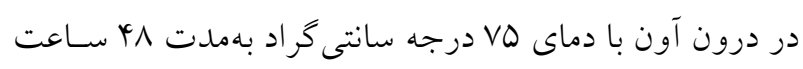

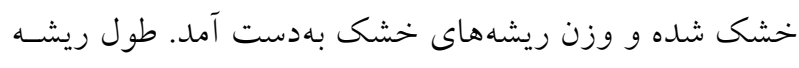

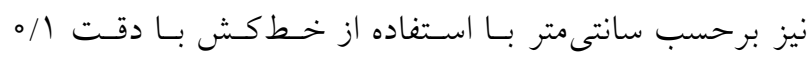

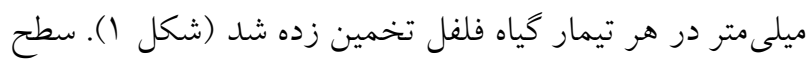

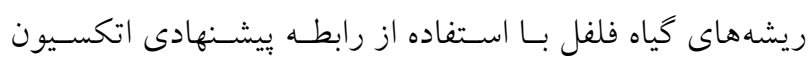

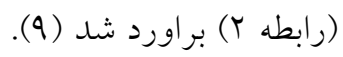

$$
\mathrm{A}=r(\mathrm{~V} \pi \mathrm{L})^{\circ / \Delta}
$$

در اين رابطه A: سطح ريشه ( ) ل

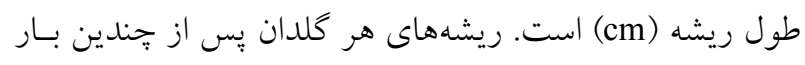

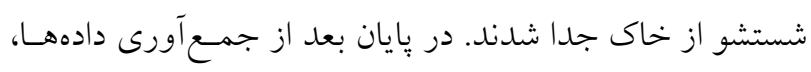

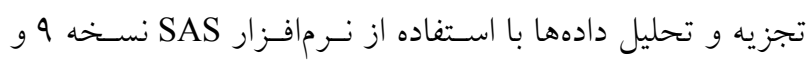

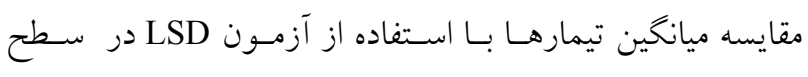

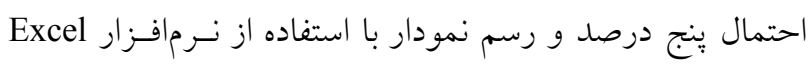

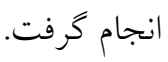

\section{بحث و نتايج}

نتايج حاصل از تجزيه واريانس در جدول (r) نشـان داده شــه آنه

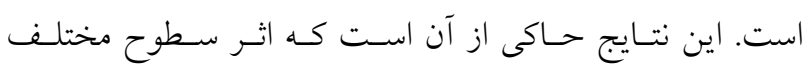


جدول r. جدول تجزيه واريانس شاخصهاى عملكرد و اجزاى عملكردو توسعه ريشه گياه فلفل

\begin{tabular}{|c|c|c|c|c|c|c|c|c|c|c|}
\hline 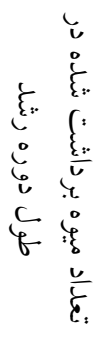 & 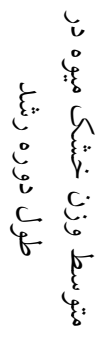 & 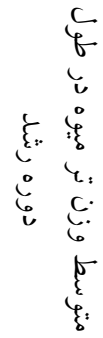 & $\begin{array}{l}\underline{c} \\
6 \\
6 . \\
6 \\
6 \\
6 \\
6 \\
0 \\
6\end{array}$ & $\begin{array}{l}\varepsilon \\
\varepsilon \\
\varepsilon\end{array}$ & $\begin{array}{l}\xi \\
\xi \\
\xi \\
c \\
c \\
6\end{array}$ & $\begin{array}{l}\xi \\
\xi \\
\varepsilon: \\
c:\end{array}$ & $\begin{array}{l}\xi \\
\varepsilon^{\xi} \\
c^{c}\end{array}$ & $\begin{array}{l}\xi \\
\xi \xi\end{array}$ & آزادى درجه & منابع تغييرات \\
\hline$\mu_{\circ / \Lambda^{*}}$ & $1 / / r^{\mathrm{ns}}$ & $r \Delta \Lambda^{*}$ & $\varphi / q^{\mu^{*}}$ & TYMT** & $T \Lambda / Q^{* *}$ & $V 10^{* *}$ & $19 \mu^{* * *}$ & $r \circ \wedge^{* *}$ & r & رزيم آبيارى \\
\hline$\mu / \mu V$ & $0 / 9 \pi$ & 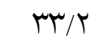 & O/O & $\mu y / 9$ &.$/ Q F$ & $r / R$ & T/NV & $9 / 09$ & $\wedge$ & خطا \\
\hline س $11 / 1$ & $4 / \Delta_{0}$ & $r / 90$ & $r / 9 \mathrm{~V}$ & $r / Q)$ & $9 / 0 \mathrm{H}$ & $r / N 1$ & $r / 01$ & $V / V^{4}$ & & ضريب تغييرات \\
\hline
\end{tabular}
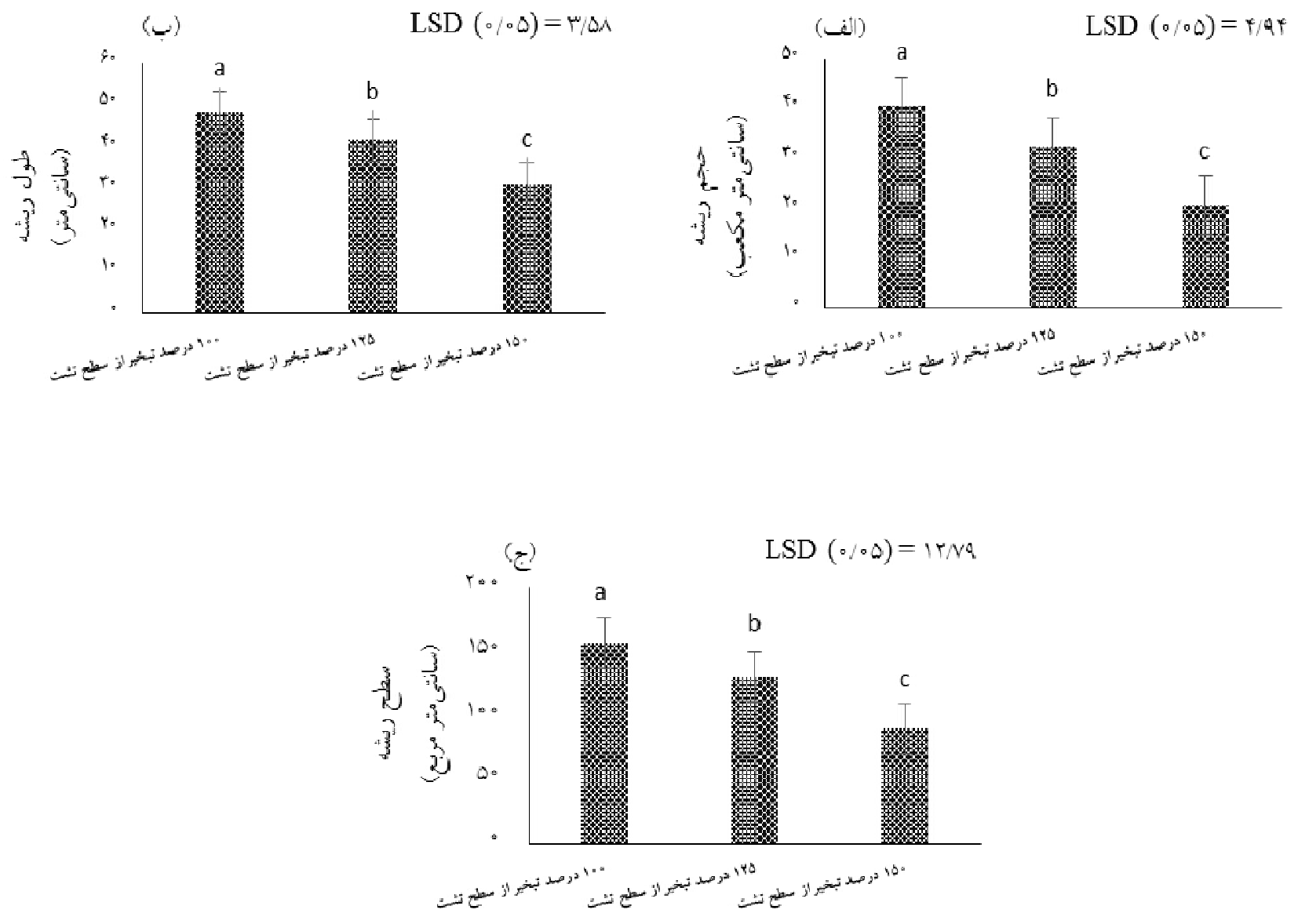

شكل r. بر رسى اثر سطوح مختلف بيش آبيارى بر: الف) حجم، ب) طول و ج) سطح ريشه گياه فلفل سبز. حروف مشترك در هر يك از

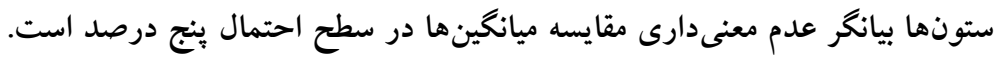




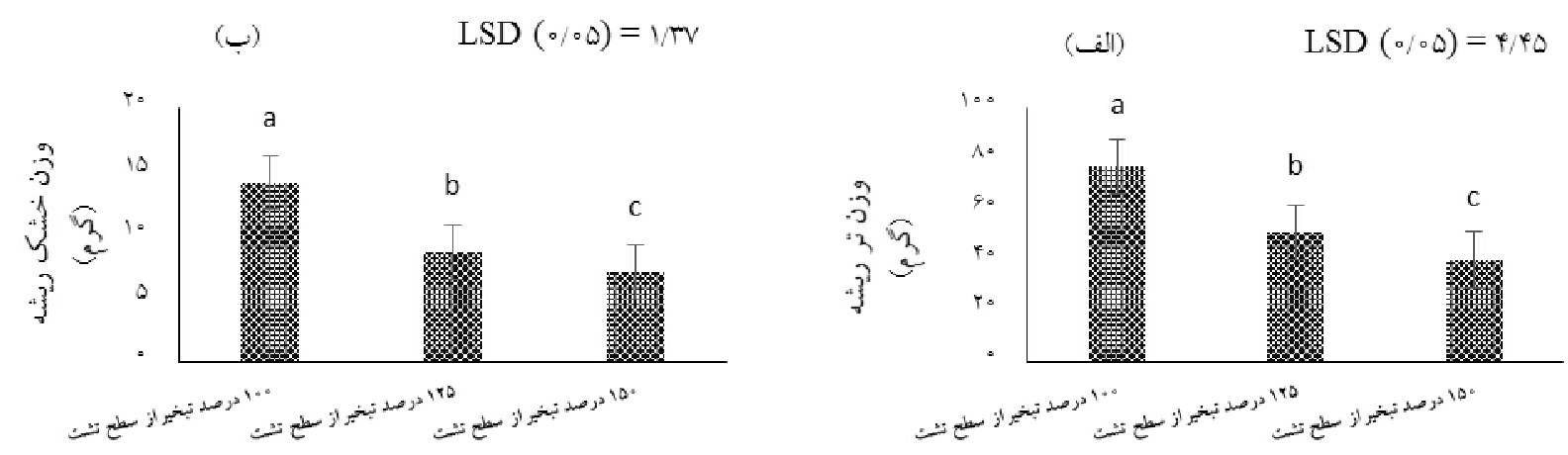

شكل r. بررسى اثر سطوح مختلف بيشآبيارى بر: الف) وزن تر و ب) وزن خشك ريشه گياه فلفل سبز. حروف مشترى در هر يك از ستونها بيانگر عدم معنىدارى مقايسه ميانخينها در سطح احتمال ينج درصد است.

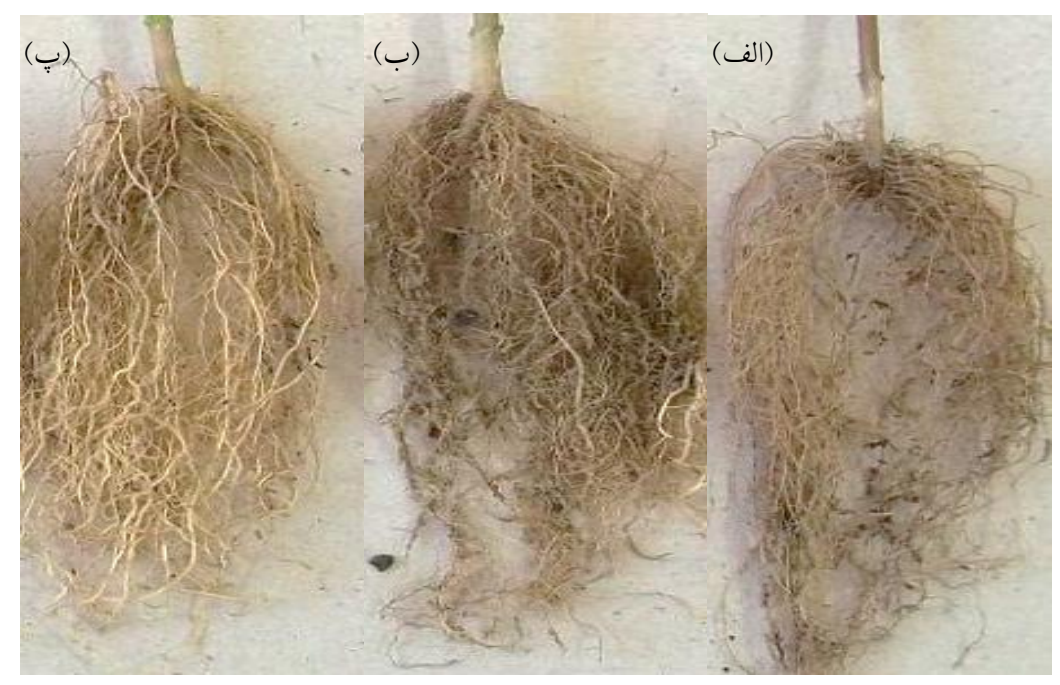

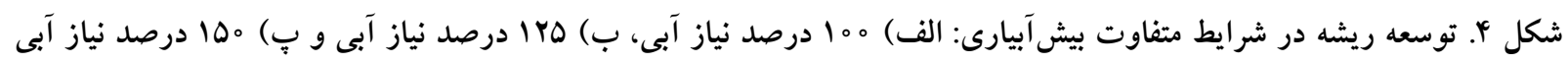

درصد)، رشد ريشه در مقايسه با دو تيمار ديخـر بسيش آبيـارى

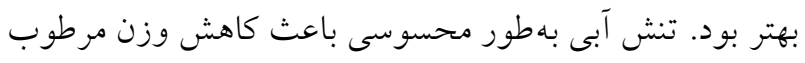

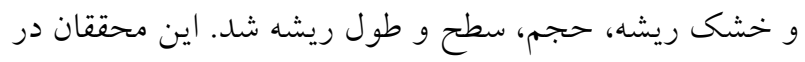

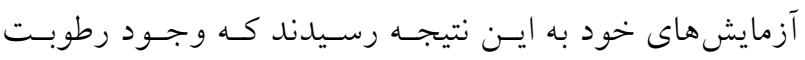
مناسب و كافى رشد ريشه را افزايش داد و با فاصـله از مقــدار

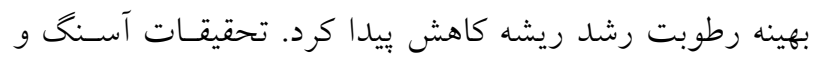

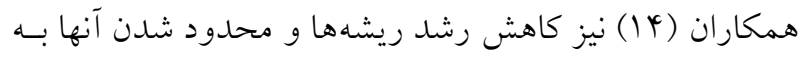

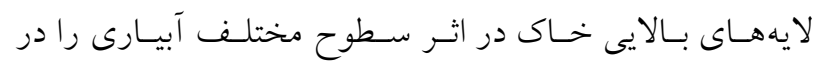

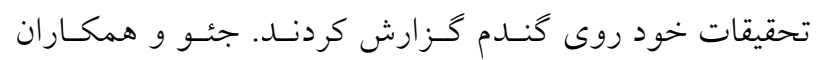

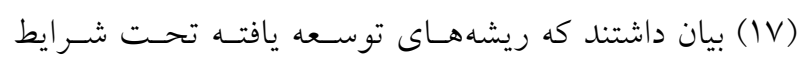

بيش آبيارى حساس بودهه و اكثر بارامترهـاى مربـوط بـه توسـعه

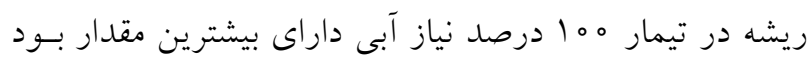

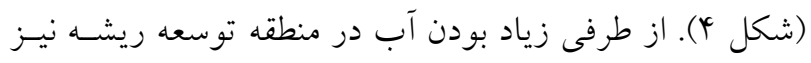

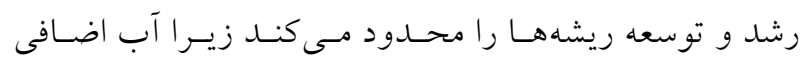

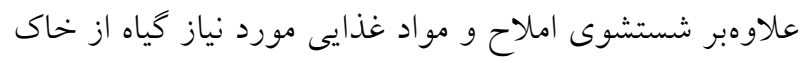

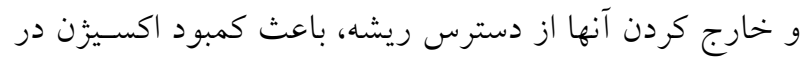

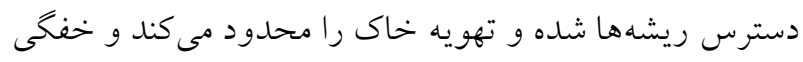
ريشه را بهدنبال خواهد داشت. الكوى توزيع طولى ريشه ريشه كيـاه

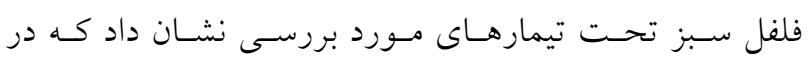

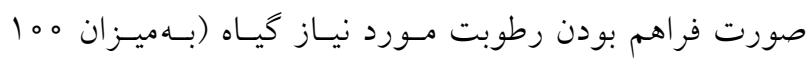




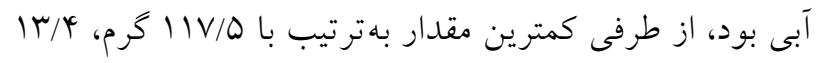

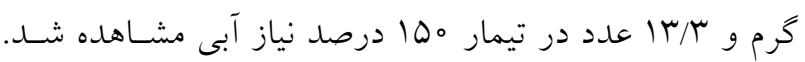
لازم به ذكر است كه بين سطوح ه ا و ها ا درصد نيـاز آبسى

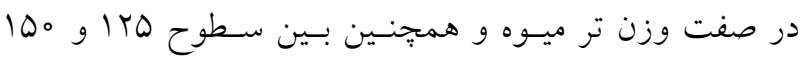
درصد نياز آبى در صفت تعداد ميوه برداشت شده در هر بوتسه. اختلاف معنى دارى در سطح ينج درصد وجود نداشت. مقايسه ميانخين وزن تر ميوه و تعداد ميوه در اثر تيمارهاى بيش آبيارى نشان داد كه افزايش ميزان آب آبيارى منجر به كاهش صـفات مذكور شد، ولى در صفت وزن خشك ميوه، روند معنسى دارى وجود نداشت. مطابق شـكل (9) بيشـترين ميـزان بهــرورىى مصـرف آب

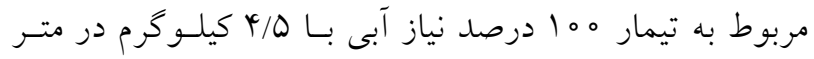
مكعب و كمترين مقـدار بــا T/D كيلـو گرم در متـر مكعسب در

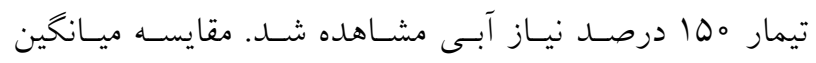
بهرهورى مصرف آب در اثر تيمارهاى بيش آبيارى نشان داد كه. افزايش ميزان آب آبيارى منجر به كاهش صفات مـذكور شـد. نتايج اين تحقيق با نتـايج سـجادى (†) روى فلفـل، سـالاريان (Y) روى فلفل، طباطبايى و همكاران (V) روى فلفل، كرناك و

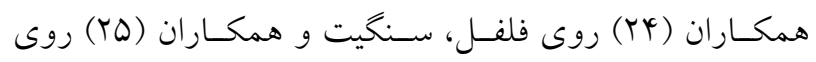
بادمجان و اوزبيس و تارى (II) روى گوجه فرنخى مطابقـت

\section{نتيجه گيرى}

عملكرد گيـاه تـابعى از توزيــع ريشـهـ و فعاليـت آن اسـت. در شرايط غرقابى، رشد و كارايى ريشه براى بهـرهورى محصـول

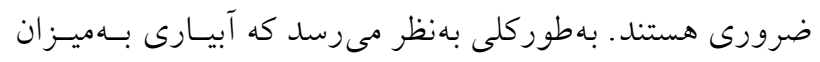

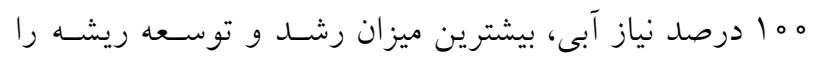
دارا بوده و در سطوح بالاتر آبيارى، رشد و توسعه ريشه كاهش

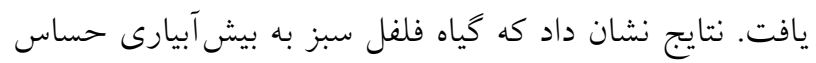
بوده و افزايش هr درصدى آب منجر به كـاهش وب درصـدى بهرهورى مصرف آب شد، هميجنين نتايج حاكى از آن است كه آبيارى بهميزان ها ا درصد نياز آبى در صفت وزن تر ميسوه در
كم آبيارى و بيش آبيارى در مقايسه با ريشههـاى توسـعه يافتـه تحت شرايط رطوبتى مطلـوب، ريزترنـــ و انشـعابات كمتـرى دارند و عمق نفوذ آنها نيز كمتر است. درحسالى كـه در شـرايط

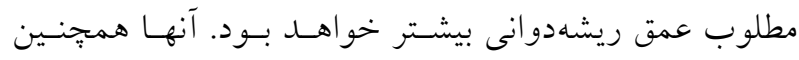
كاهش جوانهزنى و محدوديت سرعت طويل شدن ريشه را بـا افزايش تنش رطوبتى كزارش كردند. افزايش ميزان آب آبيارى و بهدنبال آن خفكى ريشه و كاهش اكسيزن باعث كاهش يكى از فاكتورهاى رشد كياه يعنى كاهش وزن ريشه و بهتبع حجـم ريشه شده اسـت. از آنجـايى كـهـ افـزايش محتـوى آب خـاى نشاندهنده كاهش هو اى خاك است كه بر بار امترهاى مختلف ريشه اثر منفى دارد، لذا كاهش وزن، حجم، سطح و طول ريشه

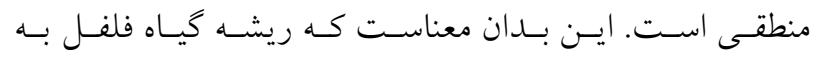
بيش آبيارى مقاوم نيست. كاهش رشد ممكن است بهطـوركلى بهعلت از دست رفتن اتساع سلولى و كاهش فعاليت ميتوزى يا مهار طويل شدن سلولها باشد (Y)). مطالعات كوهى جله كران و همكاران (0 1) نشان مىدهد كه آبيارى با فراوانى زياد مانند آبيارى قطرهاى كه محيط را اشباع نخه مىدارد، عامـل محسـدود شدن رشد ريشه ذرت دانهاى در عمقهاى مختلف خاك است. اثر مضر غرقاب شدن خاك بر رشد ريشه عمدتاً بهدليل كمبود اكسيزن در محيط بير امون ريشه اسـت. ايسن كمبـود اكسـيزن، تأثير خود را بر متابوليسم ريشه، بهصورت مختل كردن تعـادل هورمونى گياه، كاهش نفوذيذيرى ريشه نسبت به آب و كاهش سرعت جذب عناصر غذايى نشان مىدهد. غرقاب شدن خاى از ساخت و جابهايى هورمونهاى سيتوكينين و جيبـرلين در

ريشه جلو كيرى مى كند (Y).

\section{عملكرد، اجزاى عملكرد و بهرهورى مصرف آب گيـاه فلفـل}

مطابق شكل (ه) بيشترين ميزان وزن تـر ميسوه و تعـداد ميـوه

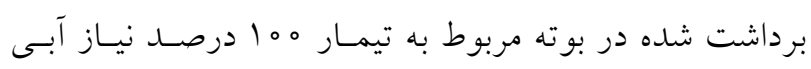

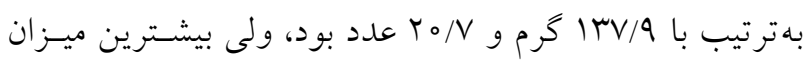
وزن خشك ميوه با // ا كرم مربوط به تيمار هץ| درصد نياز 

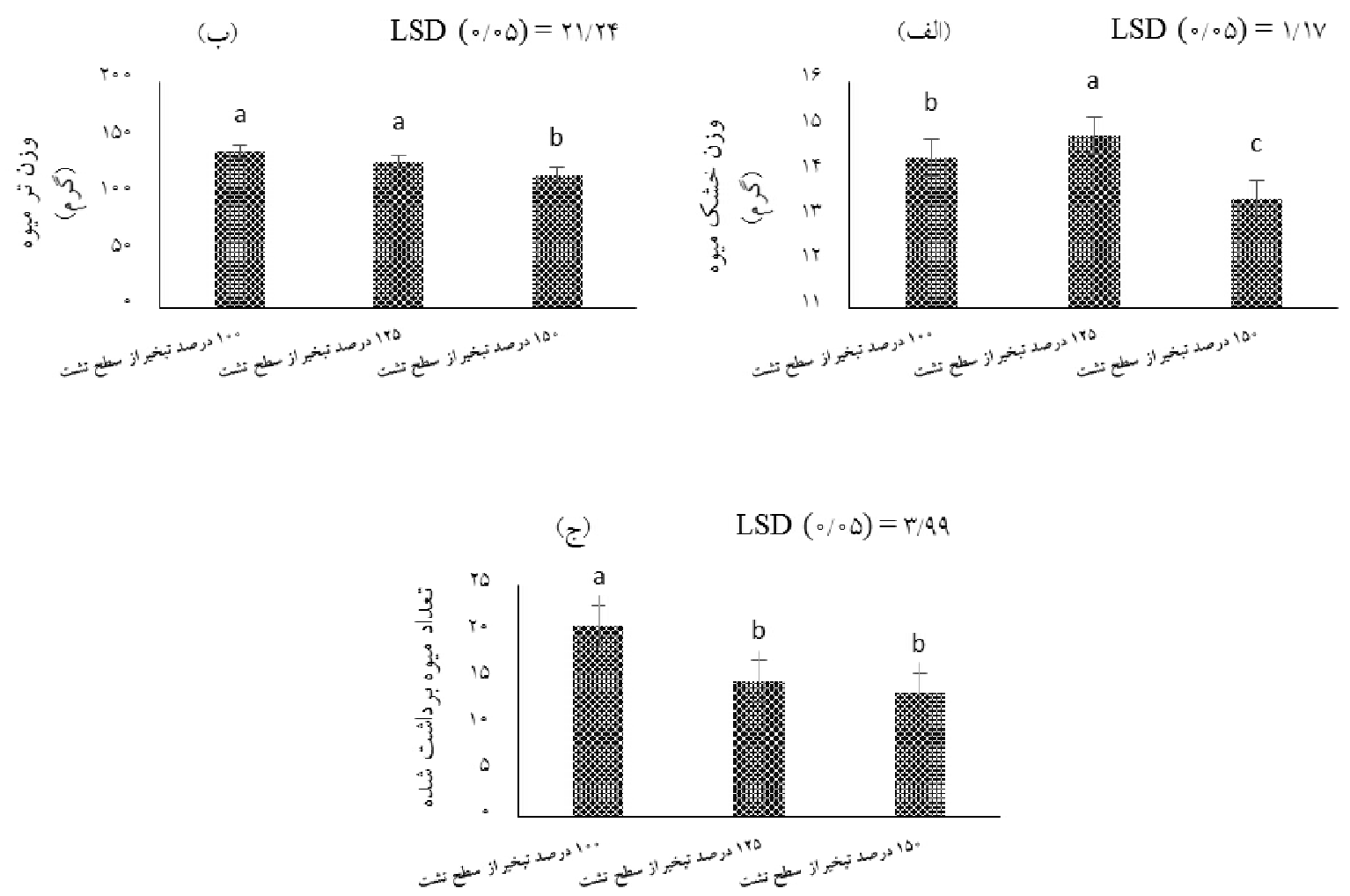

شكل ه. بررسى اثر سطوح مختلف بيش آبيارى بر الف) وزن تر ميوه، ب) وزن خشك ميوه و ج) تعداد ميوه برداشت شده در بوته كياه فلفل سبز.

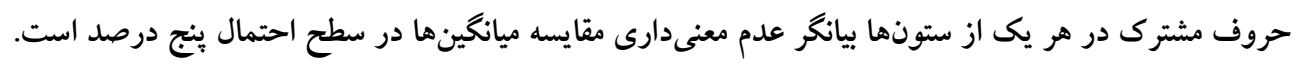

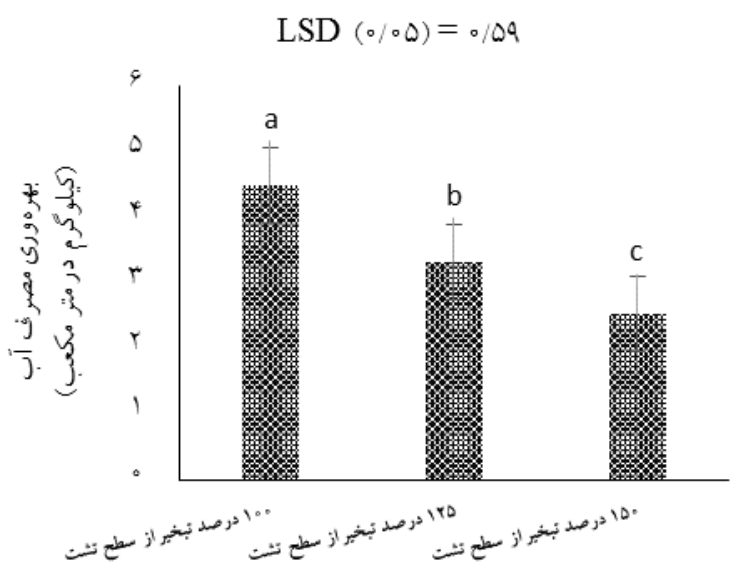

شكل 9. بررسى اثر سطوح مختلف بيش آبيارى بر بهرهورى مصرف آب مبتى بر وزن تر ميوه گياه فلفل سبز. حروف مشترى در هر يكى از

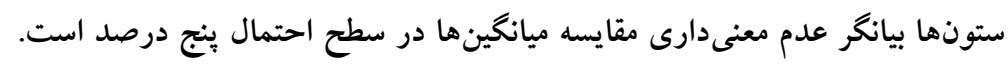




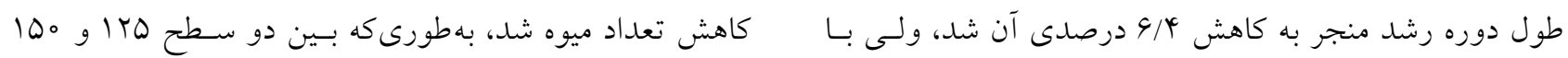
تيمار شاهد تفـاوت معنى دار آمـارى در سـطح احتمـال يـنج درصد اختلاف معنى دارى وجود نداشـت ولهى در مقايسـه بـا

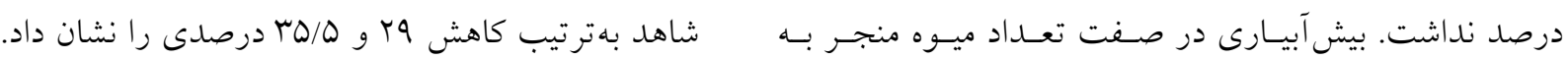

منابع مورد استفاده

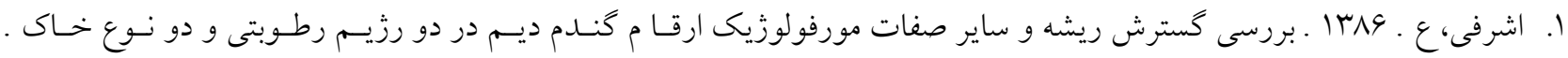
پاياننامه كارشناسى ارشد زراعت، دانشكده كشاورزى دانشخاه صنعتى اصفهان. ז. حيدرى، ن.، ج. خيرابى، م. علايى، ع. ا.فرشى، ب. كاظمى، ز. وزيرى، م. ر. انتصارى، ح. دهقانى سانيج، م. ح. سادات ميـرى و م.

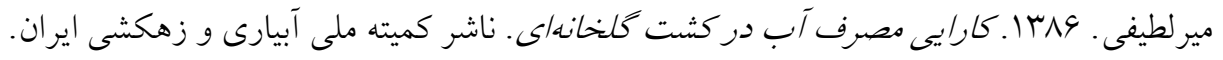

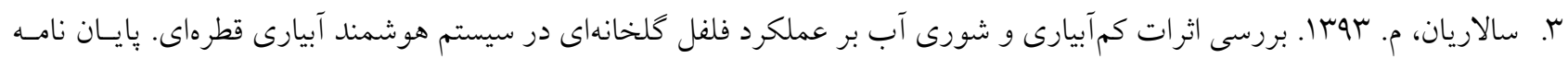
كارشناسى ارشد آبيارى و زهكشى. دانشخاه فردوسى مشهد.

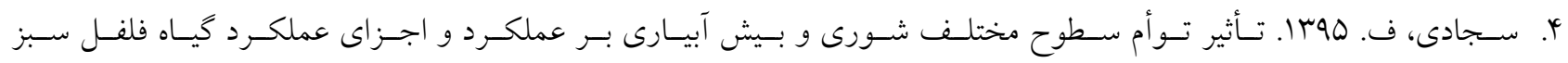
(Capsicum annum L.)

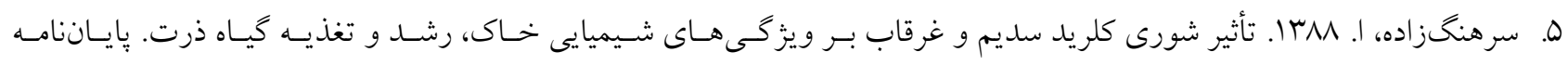
كارشناسى ارشد. دانشكده كشاورزى. دانشخاه تبريز.

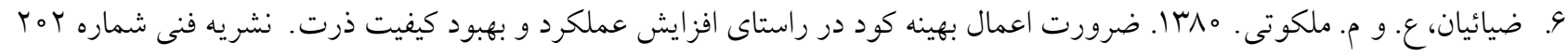
ايران، موسسه تحقيقات خاى و آب، تهران. V. طباطبائى، س. ح.، س. مردانىنزاد و ح. زارع ابيانه. سوبا. اثر تنش آبى بر رشد، عملكـرد و كـارايى مصـرف آب فلفـل در شـرايط

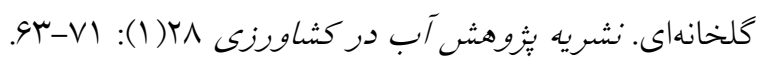

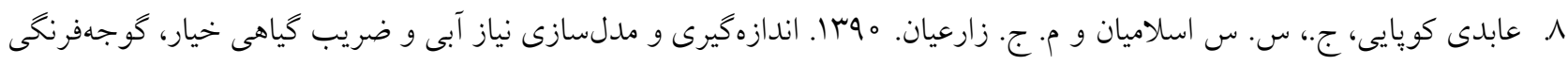

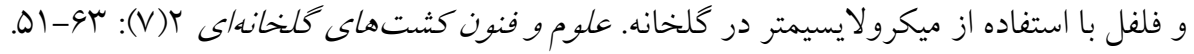

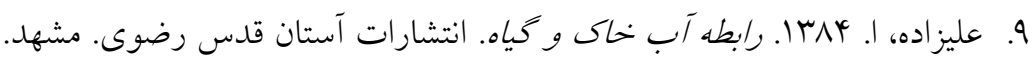

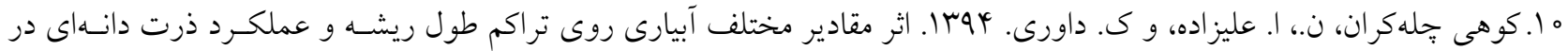

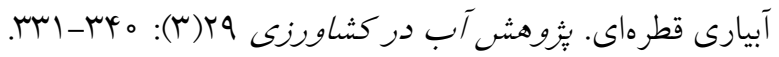

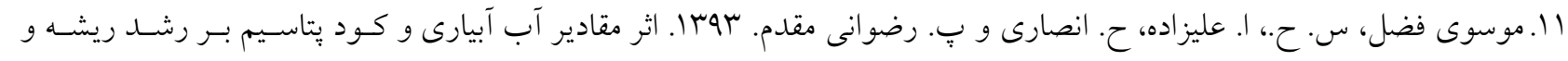

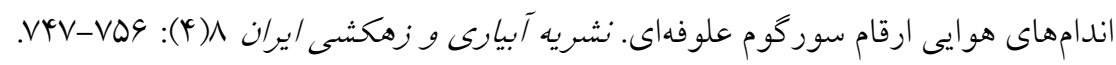

Y ا. نوح ييشه، ز. و خ. منو جهرى كلانترى. •وبا. اثرات كاربرد متقابل اسيرميدين و تنش شورى در كياه فلفل. مجله زيست شناسى /يران

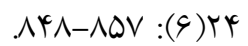

13. Allen, R. G., Preira, L. S., Raes, D. and M. Smith 1998. Crop Evapotranspiration Guidelines for Computing Crop Water Requirement. FAO Irrigation and Drainage paper, NO.56, Rome, Italy.

14. Asseng, S., J. T. Ritchie, A. J. M. Smucker and M. J. Robertson. 1998. Root growth and water uptake during water deficit and recovering in wheat. Plant and Soil 201: 265-273.

15. Bernardino, D. F. M. and C. J. R. Carvalho. 2000. Physiological and morphological responses of Barchiaria Spp. To flooding. Pesquisa Agropecuária Brasileira 35: 1954-1966.

16. Doorenbod, J. and W.O. Pruitt. 1977. Crop Water Requirement. FAO Irrigation and Drainage Paper No. 24, FAO, 
Rome.

17. Guo, A. H., G. SH. Liu, SH. Q. An, S. X. Ren and R. N. Lin.. 2002. Effect of limited water supply on root growth and development of winter weat and the characters of soil moisture use before planting. Journal of Applied Meteorology and Climatology 13 (5): 621-626.

18. Lebowski, C. A. M., R. H. Dowdy, R. R. Allmars and J. A. Lamb. 1998. Soil strength and water content influences on corn root distribution in a sandy soil. Plant and Soil 203: 239-247.

19. Marshner, H. 1995. Mineral Nutrient of Higher Plants. Academic Press, London.

20. Ozbahce, A. and A. F. Tari. 2010. Effects of different emitter space and water stress on yield and quality of processing tomato under semi-arid climate conditions. Agricultural Water Management 97(9): 1405-1410.

21. Khan, M. A. I., A. M. Farooque, M. A. Haque, M. A. Rahim and M. A. Hoque. 2008. Effects of water stress at various growth stages on the physio-morphological characters and yield in chilli. Bangladesh Journal of Agricultural Research 33: 353-362.

22. Kirnak, H., Z. Gokalp, H. Demir, S. Kodal and E. Yildirim. 2016. Paprika Pepper Yield and Quality as Affected by Different Irrigation Levels. Tartm Bilimleri Dergisi 22(1): 77-88.

23. Pandey, R. K., J. W. Maranville and A. Admou. 2001. Tropical wheat response to irrigation and nitrogen in a Sahelian environment. I. Grain yield, yield components and water use efficiency. European Journal of Agronomy, 15: 93-105.

24. Senyigit, U., A. Kadayifci, F. O. Ozdemir, H. Oz and A. Atilgan. 2011. Effects of different irrigation programs on yield and quality parameters of eggplant (Solanum melongena L.) under greenhouse conditions. African Journal of Biotechnology 10(34): 6497.

25. Shah, F. R., N. Ahmad, K. R. Masood and D. M. Zahid. 2008. The influence of cadmium and chromium on the biomass production of shisham (Dalbergia sissoo roxb.) seedlings. Pakistan journal of botany 40(4): 1341-1348.

26. Yuan, B. Z., Y. Kang and S. Nishiyama. 2001. Drip irrigation scheduling for tomatoes in unheated greenhouse. Irrigation Science 20: 149-154. 


\title{
Investigation the Effect of Different Irrigation Regimes on Root Development and Water Use Efficiency on Green Pepper
}

\author{
F. Sajadi, H. Sharifan and S. Jamali ${ }^{*}$
}

(Received: February 27-2017 ; Accepted: May 17-2017)

\begin{abstract}
Yield is a function of root distribution and activity. In flood conditions, root growth and efficiency are essential for crop productivity. The goal of this study was to investigate the effect of different irrigation regimes on the root development, yield and yield components of green pepper (green Hashemi cultivars). This study, which was based on a completely randomized design with three replications under greenhouse conditions, was done at Gorgan University of Agricultural Sciences and Natural Resources in 2016. Different irrigation regimes consisted of 3 levels $(100,125$ and 150 percent of water requirement). The results showed that the effect of different irrigation regimes on root volume, root length, root area and number of fruit was significant at 1 percent level $(\mathrm{P}<0.01)$, but water use efficiency, and fresh and dry weight of fruit were significant at 5 percent level $(\mathrm{P}<0.05)$. The results also revealed that green pepper plants were sensitive to over irrigation. Increasing irrigation levels from 100 to 125 percent of pan evaporation resulted in the reduction of root volume, root length, water use efficiency, number of fruits, and pepper fresh weight to 20,13.8,26,29and 6.4 percent, respectively. As the conclusion, with the increase in water irrigation level, the fresh weight of the fruit was significantly decreased.
\end{abstract}

Keywords: Fruit fresh weight, Number of fruit, Over irrigation, Root volume and area, Root volume, Water use efficiency.

1. Department of Water Engineering, Faculty of Soil and Water Engineering, Gorgan University of Agricultural Sciences and Natural Resources, Gorgan, Iran.

*: Corresponding Author, Email: sa13e12@gmail.com 